\title{
Penggunaan Smartphone Bermasalah Pada Siswa SMA Serta Implikasinya Bagi Pelayanan Bimbingan dan Konseling di Sekolah
}

\author{
Nira Prihatin Nufus ${ }^{*}{ }^{1}$, Susi Fitri ${ }^{2}$, Murti Kusuma Wirasti ${ }^{3}$
}

1,2,3Program Studi Magister Bimbingan dan Konseling, Universitas Negeri Jakarta, Indonesia.

*)1Corresponding author, ఏe-mail: niraprihatinnufus_1108817019@mhs.unj.ac.id
Received:
Accepted:
Published:

16 September 2020

02 November 2020

29 December 2020

\begin{abstract}
Excessive use of smartphones can lead to problematic smartphone use. Problematic smartphone use is a person's inability to regulate smartphone use, which results in many negative consequences in everyday life. This study aims to determine the problematic description of smartphone use in high school students in the Bogor area. This research uses a quantitative approach with descriptive methods. The sampling technique was using the purposive sampling technique. The research instrument used was the MPPUSA (Mobile Phone Problem Use Scale for Adolescent) adaptation instrument. Its aspects consist of tolerance, escape from problems, craving, withdrawal, negative consequences, and social motivation. The results of the instrument trial obtained a reliability coefficient of 0.877 . The questionnaire was distributed online using the Google Forms application, with 188 respondents ( 45 male respondents and 143 female respondents). The scale used is the five-point Likert scale. The results showed that the category of problematic use was $8.50 \%$, the users were at risk of $43.62 \%$, habitual use was $40.96 \%$, and occasional users were $6.91 \%$. The highest percentage of problematic smartphone use aspects is the escape from problem aspect of $67.84 \%$ and the lowest is the withdrawal aspect of $43.09 \%$. The implication of the results of this study can be used as a needs analysis in making guidance and counseling service programs in schools by guidance and counseling teachers.
\end{abstract}

Keywords: Problematic Smartphone Use, Guidance and Counseling, High School Student, School Counselor

\begin{abstract}
Abstrak
Penggunaan smartphone yang berlebihan dapat mengarah pada terjadinya penggunaan smartphone bermasalah. Penggunaan smartphone bermasalah (problematic smartphone use) merupakan ketidakmampuan seseorang untuk mengatur penggunaan smartphone, yang mengakibatkan banyak konsekuensi negatif dalam kehidupan sehari-hari. Penelitian ini bertujuan untuk mengetahu gambaran problematic smartphone use pada siswa remaja SMA di wilayah Bogor. Penelitian ini menggunakan pendekatan kuantitatif dengan metode deskriptif. Teknik pengambilan sampel dengan cara teknik purposive sampling. Instrumen penelitian yang digunakan adalah instrumen adaptasi MPPUSA (Mobile Phone Problem Use Scale for Adolescent). Aspek-aspeknya terdiri dari tolerance, escape from problem, craving, withdrawal, negative consequence, dan social motivation. Hasil uji coba instrumen mendapatkan koefisien reliabilitas 0,877. Kuesioner disebarkan secara online menggunakan aplikasi Google Formulir, responden berjumlah 188 orang (45 orang laki-laki dan 143 orang perempuan). Skala yang digunakan adalah skala likert lima poin. Hasil penelitian menunjukkan bahwa pada kategori pengguna smartphone bermasalah sebesar $8,50 \%$, pengguna beresiko sebesar $43,62 \%$, pengguna biasa sebesar $40,96 \%$, dan pengguna sesekali sebesar 6,91\%. Persentase aspek yang paling tinggi pada instrumen problematic smartphone use adalah aspek escape from problem sebesar $67,84 \%$ dan terendah adalah aspek withdrawal sebesar 43,09\%. Implikasi dari hasil penelitian ini dapat dijadikan sebagai analisis kebutuhan dalam pembuatan program layanan bimbingan dan konseling di sekolah oleh guru BK.
\end{abstract}

Kata Kunci: Penggunaan Smartphone Bermasalah, Bimbingan dan Konseling, Siswa SMA, Konselor Sekolah 
How to Cite: Nufus, N. P., Fitri, S., \& Wirasti, M. K. (2020). Penggunaan Smartphone Bermasalah Pada Siswa SMA Serta Implikasinya dalam Pelayanan Bimbingan dan Konseling di Sekolah. ENLIGHTEN: Jurnal Bimbingan Konseling Islam, 3(2), 96-105. https://doi.org/10.32505/enlighten.v3i1.1582

\section{PENDAHULUAN}

Smartphone merupakan bagian integral dari kehidupan sehari-hari yang memiliki kemampuan multifungsi. Kehadiran smartphone telah mengubah cara orang terlibat dalam kehidupan pribadi dan profesionalnya. Selain bertindak sebagai smartphone, smartphone memberi pengguna akses seluler ke internet dan berbagai macam aplikasi di dalamnya (Winskel, Kim, Kardash, \& Belic, 2019).

Dijelaskan oleh Bohang (2018) bahwa jumlah pengguna internet di Tanah Air sepanjang 2017 mencapai 143 juta orang, dan pada tahun 2018 mencapai 171 juta orang. Artinya, terdapat pertumbuhan pengguna internet sebesar $10,12 \%$ selama satu tahun (APJII, 2018). Jumlah tersebut menunjukkan lebih dari 60 persen penduduk Indonesia telah bisa mengakses internet. Jumlah tersebut akan menjadikan Indonesia sebagai negara dengan pengguna aktif smartphone terbesar keempat setelah China, India, dan Amerika (Novalius, 2018).

Hasil survey nasional profil perilaku oleh APJII (2018), pengguna internet pada usia Sekolah Menengah Atas (15-19 tahun) sebesar 91\% dibanding dengan bukan pengguna internet diusianya. Berdasarkan latar belakang pendidikan, persentase pengguna internet yang sedang menempuh Sekolah Menengah Atas sebanyak 90,2\%. Penetrasi pengguna internet berdasarkan pekerjaan, sebanyak $71,8 \%$ pelajar menggunakan internet dibanding dengan yang tidak menggunakan. Persentase tertinggi pengguna internet membutuhkan waktu lebih dari 8 jam untuk mengakses internet setiap harinya $(19,6 \%)$, dan 93,9\% pengguna internet mengakses internet setiap hari melalui perangkat smartphone.

Penggunaan smartphone di sekolah dapat dimanfaatkan sebagai media pembelajaran (Ismanto, Novalia, \& Herlandy, 2017). Hal tersebut dapat memberikan kesempatan belajar bagi siswa yang lebih mendalam karena dengan menggunakan smartphone siswa dapat mengembangkan pembelajaran melalui penelusuran informasi dari internet (Rogozin, 2012).

Penelitian yang dilakukan oleh Mardhiyatun (2015), memperlihatkan bahwa smartphone mempermudah komunikasi antara siswa dengan guru BK, informasi lebih cepat diterima, mampu meningkatkan minat siswa dalam berkonsultasi, serta dapat membantu masalah yang dikonsultasikan oleh siswa. Banyak manfaat yang didapatkan dari smartphone, namun jika salah menerapkannya hal tersebut dapat merugikan semuanya (Widharsa, 2018).

Di samping memiliki banyak manfaat, smartphone juga memiliki dampak negatif, yaitu penggunaan smartphone yang 
bermasalah. Penggunaan telepon seluler yang bermasalah adalah fenomena yang muncul di masyarakat kita, dan secara khusus mempengaruhi populasi remaja (López-Fernández, Honrubia-Serrano, \& Freixa-Blanxart, 2012).

Problematic smartphone use (penggunaan smartphone yang bermasalah) merupakan ketidakmampuan individu untuk mengatur penggunaan smartphone, yang mengakibatkan banyak konsekuensi negatif dalam kehidupan sehari-hari, termasuk gejala ketergantungan dan masalah sosial, perilaku, dan afektif dalam kehidupan individu (Billieux, 2012; Lopezfernandez, 2013). Aspek-aspek problematic smartphone use meliputi tolerance (toleransi), escape from problem (melarikan diri dari masalah), withdrawal (penarikan), craving (perasaan mengidam), negative consequence (konsekuensi negative), dan social motivation (motivasi sosial) (Bianchi \& Phillips, 2005; Lopez-fernandez, 2013).

Penggunaan smartphone yang berlebihan dapat mengarah pada terjadinya penggunaan smartphone bermasalah. Hal itu dapat menyebabkan konsekuensi tertentu, seperti membuat seseorang menjadi murung saat tidak bisa menggunakan smartphone, membuat tidak peduli dengan lingkungan sekitar, terjadinya penurunan konsentrasi, daya serap dan minat belajar (Kwon et al., 2013; Tri, 2014; Wati, 2017).

Penelitian yang dilakukan oleh Yuni \& Pieewan (2016) menemukan terdapat hubungan negatif antara intensitas penggunaan smartphone dengan disiplin belajar siswa. Artinya semakin tinggi intensitas penggunaan smartphone, Enlighten: Jurnal Bimbingan Konseling Islam $\approx$ Vol 3 No 2 maka semakin rendah disiplin belajar siswa, begitu juga sebaliknya.

Penelitian juga menunjukkan bahwa penggunaan smartphone yang bermasalah berpengaruh pada rendahnya kualitas tidur remaja (Kwon et al., 2013; Nalwa \& Anand, 2004; Putri, 2018). Penggunaan smartphone yang terusmenerus dan meningkatnya keterjagaan setiap malam dapat mengakibatkan masalah tidur remaja serta dapat berpengaruh pada rendahnya self-esteem, meningkatnya kecemasan dan juga depresi (Widuri, 2010; Woods \& Scott, 2016).

Wawancara yang dilakukan pada beberapa guru BK di wilayah Bogor, mengungkapkan bahwa sekolah memperbolehkan siswa membawa smartphone ke sekolah. Penggunaan smartphone bermasalah yang terdapat di sekolah seperti menggunakan smartphone tanpa seizin guru saat KBM berlangsung (main games, chatting, nonton video, mengecek pemberitahuan); menyontek pada saat ujian (searching jawaban, lihat contekan yang sudah disediakan sebelumnya); terjadinya cyberbullying; dan juga ada siswa yang suka mengakses konten dewasa. Hal tersebut mengakibatkan siswa menjadi tidak fokus saat KBM berlangsung, terjadi penurunan prestasi akademik, terlambat datang ke sekolah karena menggunakan smartphone hingga larut malam. Berdasarkan paparan di atas maka peneliti tertarik untuk meneliti tentang gambaran problematic smartphone use pada siswa jenjang SMA di wilayah Bogor. 


\section{METODE}

Penelitian survei dilakukan pada siswa jenjang SMA di wilayah Bogor menggunakan purposive sampling. Kriteria responden diantaranya yaitu memiliki perangkat smartphone, siswa jenjang SMA berusia 15-19 tahun, dan bersekolah di wilayah Bogor. Survei disebar menggunakan aplikasi google formulir selama satu minggu di bulan Mei 2020. Sebanyak 188 orang responden (143 perempuan, 45 laki-laki) diperoleh dari berbagai sekolah negeri dan swasta di wilayah Bogor.

Instrumen yang digunakan yaitu angket hasil adaptasi dari MPPUSA (Mobile Phone Problem Use Scale for Adolescent). Terdiri dari enam aspek diantaranya yaitu tolerance, escape from problems, withdrawal, craving, negative consequence, dan social motivation. Uji validitas yang digunakan adalah validitas konstruk dan validitas empirik. Hasil uji coba instrumen mendapatkan koefisien reliabilitas 0,877. Terdapat 26 butir pernyataan yang ditanggapi menggunakan skala likert 5 poin $(1=$ tidak pernah, $2=$ jarang, $3=$ kadang-kadang, $4=$ sering, 5 = selalu).

Adaptasi instrumen dikembangkan dengan menggunakan prosedur back translation. Melibatkan dua ahli bahasa berlisensi serta satu dosen dalam ilmu pendidikan dan budaya. Hasilnya, satu butir pernyataan dimodifikasi guna disesuaikan dengan situasi siswa di sekolah. Yaitu pada butir pernyataan nomor 24 : "Saya pernah terlibat masalah lebih dari sekali karena ponsel saya berbunyi selama rapat, perkuliahan, atau saat di dalam bioskop", menjadi : "Saya pernah terlibat masalah lebih dari sekali karena smartphone saya berbunyi saat pelajaraan."

Kategorisasi penskoran problematic smartphone use dibagi menjadi empat, yaitu pengguna bermasalah, pengguna beresiko, pengguna biasa, dan pengguna sesekali.

\section{HASIL TEMUAN}

Survei problematic smartphone use melalui Google Formulir telah dilaksanakan. Sebanyak 188 tanggapan diperoleh dari siswa-siswi jenjang SMA di wilayah Bogor. $76 \%$ responden siswa perempuan, dan $24 \%$ responden siswa lakilaki. Responden paling banyak yang mengisi berada pada usia 17 tahun, yaitu sebanyak 51,1\%. Responden usia 16 tahun sebanyak 33,5\%; usia 18 tahun sebanyak $11,7 \%$ dan terendah pada usia 15 tahun sebanyak $3,7 \%$.

Tabel 1. Distribusi Frekuensi dan Persentase Problematic Smartphone Use

\begin{tabular}{cccc}
\hline Interval Skor & Kategori & Frekuensi & \% \\
\hline$>87$ & Pengguna bermasalah & 16 & 8.5 \\
$67-86$ & Pengguna beresiko & 82 & 43.62 \\
$47-66$ & Pengguna biasa & 77 & 40.96 \\
$<47$ & Pengguna sesekali & 13 & 6.92 \\
& Total & 188 & 100 \\
\hline
\end{tabular}

Enlighten: Jurnal Bimbingan Konseling Islam $\approx$ Vol 3 No 2 
Berdasarkan tabel 1 menunjukan bahwa sebanyak 8,5\% (16 siswa) berada pada kategori pengguna smartphone bermasalah, 43,62\% (82 siswa) berada pada kategori pengguna smartphone beresiko, 40,96\% (77 siswa) berada pada kategori pengguna smartphone biasa, dan 6,91\% (13 siswa) berada pada kategori pengguna smartphone sesekali. Dari hasil persentase tersebut dapat terlihat bahwa penggunaan smartphone bermasalah pada siswa di wilayah Bogor paling banyak berada pada kategori pengguna smartphone beresiko. Mengikuti literatur tentang penggunaan Internet yang bermasalah, 52,12\% dari responden dapat dianggap sebagai pengguna yang berpotensi bermasalah (kombinasi kategori berisiko dan masalah).

Tabel 2. Persentase Problematic Smartphone Use Per Aspek

\begin{tabular}{lcc}
\hline Aspek & Total Skor & Persentase \\
\hline Tolerance & 1593 & $56.49 \%$ \\
Escape from problems & 1913 & $67.84 \%$ \\
Withdrawal & 1215 & $43.09 \%$ \\
Craving & 1398 & $49.57 \%$ \\
Negative consequences & 5469 & $48.48 \%$ \\
Social motivations & 1049 & $55.80 \%$ \\
\hline
\end{tabular}

Tabel 2 menunjukkan bahwa pada aspek tolerance mendapatkan skor 1593 dengan persentase sebesar $56.49 \%$, aspek escape from problems mendapatkan skor 1913 dengan persentase sebesar 67.84\%, aspek withdrawal mendapatkan skor 1215 dengan persentase sebesar $43.09 \%$, aspek craving mendapatkan skor 1398 degan persentase $49.57 \%$, aspek negative consequences mendapatkan skor 5469 dengan persentase $48.48 \%$, dan aspek social motivations mendapatkan skor 1049 dengan persentase sebesar $55.80 \%$. Ini merupakan hasil keseluruhan sampel $(n=188)$ pada setiap aspek pada instrumen problematic smartphone use.

\section{PEMBAHASAN}

Bentuk baru MPPUSA ini menunjukkan keandalan yang lebih besar daripada MPPUS yang asli (Bianchi \& Phillips, 2005). Selain itu, peneliti menggunakan MPPUSA sebab target sasaran pada penelitian ini merupakan siswa sekolah menengah/ remaja. Kelompok siswa sekolah menengah merupakan kelompok utama dari pengguna berisiko (Kawasaki et al., 2006).

Penggunaan smartphone bermasalah pada siswa di wilayah Bogor mendapatkan persentase terbesar yaitu pada aspek escape from problems (melarikan diri dari masalah) sebanyak 67,84\%. Bentuk penggunaan smartphone bermasalah pada aspek escape from problems seperti: menggunakan smartphone untuk membuat diri merasa lebih baik saat sedang merasa sedih, menggunakan smartphone untuk bicara dengan orang lain ketika sedang merasa sendirian, dan memilih untuk menggunakan smartphone alih-alih mengerjakan hal lain yang sifatnya lebih mendesak. Seringkali ketika siswa mengalami kesulitan dalam pengerjaan Enlighten: Jurnal Bimbingan Konseling Islam $₫$ Vol 3 No 2 
tugas, ia beralih pada penggunaan smartphone. Hal ini menjadi salah satu bentuk multitasking yang juga menjadi pengalihan tugas yang menyenangkan (David, Kim, Brickman, Ran, \& Curtis, 2015).

Penggunaan smartphone bermasalah pada aspek tolerance (toleransi) sebanyak $56,49 \%$. Bentuk penggunaan smartphone bermasalah pada aspek tolerance seperti: tidak memiliki waktu yang cukup untuk menggunakan smartphone, penggunaan smartphone telah meningkat 12 bulan terakhir, dan jadi menghabiskan lebih banyak waktu daripada yang seharusnya. Penelitian yang dilakukan oleh Csibi, Griffiths, Demetrovics, \& Szabo (2019) kelompok usia sekolah menengah memiliki nilai tertinggi pada aspek toleransi. Mahmoodi et al., (2018) juga mengungkapkan bahwa penggunaan smartphone yang berlebihan mendorong perilaku bermasalah yang telah meningkat secara luas di kalangan siswa sekolah menengah di negara-negara berkembang (Nengsih, 2018).

Penggunaan smartphone bermasalah pada aspek social motivation (motivasi sosial) sebanyak 55,80\%. Bentuk penggunaan smartphone bermasalah pada aspek ini seperti: jika tidak memiliki smartphone, teman-teman akan kesulitan menghubungi; dan juga teman-teman tidak suka jika smartphone dimatikan/ dalam keadaan mode senyap (silent). Penelitian yang dilakukan oleh Kim \& Hwang dalam Lee \& Lee (2017) para remaja menganggap hubungan teman sebaya adalah penting. Alhasil, mereka berusaha menjaga hubungan intim dengan teman-temannya. Enlighten: Jurnal Bimbingan Konseling Islam « Vol 3 No 2
Jika tidak, mereka cenderung merasa kesepian dan terasing, membuat mereka mengarah pada penggunaan smartphone bermasalah.

Penggunaan smartphone bermasalah pada aspek craving sebanyak 49,57\%. Bentuk penggunaan smartphone bermasalah pada aspek craving, seperti: pernah mencoba mengurangi waktu untuk menggunakan smartphone namun tidak berhasil; merasa cemas jika belum mengecek pesan atau menghidupkan smartphone selama beberapa waktu; dan menjadi lekas marah jika harus mematikan smartphone selama pelajaran, saat makan, atau saat di dalam bioskop. Penelitian yang dilakukan oleh Lee et al., (2017) menunjukkan bahwa pemisahan smartphone memiliki efek positif pada kinerja akademik di ruang kelas.

Penggunaan smartphone bermasalah pada aspek negative consequence penelitian ini yaitu sebanyak 48,48\%. Bentukbentuknya seperti: terlalu asyik menggunakan smartphone ketika seharusnya mengerjakan hal-hal lain, dan ini menimbulkan masalah; pernah mencoba merahasiakan dari orang lain berapa banyak waktu yang dihabiskan untuk menggunakan smartphone; kehilangan waktu tidur akibat waktu yang dihabiskan untuk menggunakan smartphone; ketika menggunakan smartphone dan sedang melakukan sebuah tugas lain, menjadi terlalu asyik dengan obrolan di smartphone dan tidak memerhatikan apa yang sedang dilakukan; merasakan sakit dan pedih yang terkait dengan penggunaan smartphone; temanteman dan keluarga mengeluhkan tentang 
penggunaan smartphone; pernah terlibat masalah lebih dari sekali karena smartphone berbunyi saat pelajaraan; dan prestasi akademik menurun sebagai akibat langsung dari waktu yang dihabiskan untuk menggunakan smartphone. Dalam satu studi Arab Saudi, 44,4\% dari peserta terkait keluhan kesehatan umum seperti sakit kepala, kesulitan berkonsentrasi, kehilangan memori, gangguan pendengaran, dan kelelahan karena penggunaan ponsel (Khan, 2008).

Penggunaan smartphone bermasalah yang memiliki persentase terendah pada penelitian ini yaitu terdapat pada aspek withdrawal (penarikan) sebanyak 43,09\%. Bentuk penggunaan smartphone bermasalah pada aspek withdrawal, seperti: saat sedang tidak ada sinyal menjadi khawatir akan panggilan telepon yang tak terjawab; merasa kesulitan saat harus mematikan smartphone/mengaktifkan mode senyap (silent); dan merasa kehilangan arah tanpa smartphone (Lopez-fernandez, 2013).

Withdrawal mengacu pada pekerjaan mental dengan perangkat, yaitu perasaan cemas atau stres jika berada di luar jangkauan. Negative consequences yang disebabkan oleh smartphone dapat disebabkan langsung oleh faktor pertama dan kedua atau mungkin karena masalah keuangan, pekerjaan atau sekolah. Craving menjadi jelas jika seseorang membutuhkan smartphone-nya untuk melepaskan diri dari perasaan negatif (Foerster, Roser, Schoeni, \& Röösli, 2015). Semakin besar tingkat penggunaan yang bermasalah, semakin besar kemungkinannya remaja harus memperhatikan masalah yang sama di antara teman-temannya. Hal ini mungkin Enlighten: Jurnal Bimbingan Konseling Islam $n$ Vol 3 No 2 menunjukkan bahwa pengguna bermasalah memiliki beberapa wawasan tentang masalah perilaku mereka sendiri (Lopez-fernandez, 2013).

Hasil penelitian ini dapat dijadikan sebagai analisis kebutuhan bagi konselor sekolah atau guru BK dalam pembuatan program pelayanan bimbingan dan konseling di sekolah (Komalasari, Wahyuni, \& Karsih, 2016). Fenomena penggunaan smartphone bermasalah pada remaja SMA telah banyak ditemukan di lapangan, sehingga guru BK perlu berperan dalam menanganinya. Intervensi perlu diberikan pada siswa-siswa yang telah diketahui dari hasil asesmen sebagai pengguna smartphone bermasalah. Juga layanan preventif perlu diberikan agar siswa-siswa tidak mengarah pada penggunaan smartphone bermasalah terutama siswa dengan hasil asesmen kategori pengguna beresiko. Hal ini merupakan bagian dari fungsi bimbingan dan konseling yaitu pemahaman, preventif, dan kuratif (Yusuf \& Nurihsan, 2010).

Penelitian ini masih memiliki keterbatasan. Alangkah baiknya jika penelitian ini dengan sampel yang lebih banyak dan lebih diperluas kembali populasinya. Mengingat bahwa penggunaan smartphone kini sudah merambah luas ke berbagai daerah di Indonesia. Serta dengan menambahkan variabel-variabel psikologis dalam penelitian.

\section{SIMPULAN}

Secara keseluruhan problematic smartphone use pada siswa jenjang SMA di 
wilayah Bogor berada pada kategori pengguna beresiko. Hal ini menunjukkan bahwa perlu adanya layanan preventif dan kuratif dari guru BK di sekolah. Sebelum memberikan pelayanan BK, hasil penelitian ini dapat dijadikan sebagai bahan analisis kebutuhan dalam pembuatan program layanan bimbingan dan konseling di sekolah.

\section{UCAPAN TERIMA KASIH}

Terima kasih peneliti ucapkan kepada pihak-pihak yang telah mendukung terlaksananya penelitian ini, siswa-siswi yang menjadi responden penelitian dan Guru BK. Serta kepada keluarga yang telah mendukung peneliti dalam penyelesaian artikel penelitian.

\section{DAFTAR PUSTAKA}

APJII. (2018). Penetrasi \& Profil Perilaku Pengguna Internet Indonesia. Apjii. Retrieved from www.apjii.or.id

Bianchi, A., \& Phillips, J. G. (2005). Psychological predictors of problem mobile phone use. Cyberpsychology and Behavior, 8(1), 39-51. https://doi.org/10.1089/cpb.2005.8.39

Billieux, J. (2012). Problematic Use of the Mobile Phone: A Literature Review and a Pathways Model. Current Psychiatry Reviews, 8(4), 299-307. https://doi.org/10.2174/1573400128035 20522

Bohang, F. K. (2018). Berapa Jumlah Pengguna Internet Indonesia? Retrieved from

https://tekno.kompas.com/read/2018/0 2/22/16453177/berapa-jumlahpengguna-internet-indonesia

Csibi, S., Griffiths, M. D., Demetrovics, Z., \& Szabo, A. (2019). Analysis of Problematic Smartphone Use Across
Different Age Groups within the Components Model of Addiction .'

David, P., Kim, J. H., Brickman, J. S., Ran, W., \& Curtis, C. M. (2015). Mobile phone distraction while studying. New Media and Society, 17(10), 1661-1679. https://doi.org/10.1177/1461444814531 692

Foerster, M., Roser, K., Schoeni, A., \& Röösli, M. (2015). Problematic mobile phone use in adolescents: derivation of a short scale MPPUS-10. International Journal of Public Health, 60(2),

277-286. https://doi.org/10.1007/s00038-0150660-4

Ismanto, E., Novalia, M., \& Herlandy, P. B. (2017). Pemanfaatan Smartphone Android Sebagai Media Pembelajaran Bagi Guru Sma Negeri 2. JURNAL Untuk Mu NegeRI, 1(1), 42-47.

Kawasaki, N., Tanei, S., Ogata, F., Burapadaja, Siriporn Loetkham, C., Nakamura, T., \& Tanada, S. (2006). Survey on cellular phone usage on students in Thailand. Nov;25(6): https://doi.org/DOI: 10.2114/jpa2.25.377

Khan, M. M. (2008). Adverse effects of excessive mobile phone use. International Journal of Occupational Medicine and Environmental Health, vol.21,no., 289-293.

Komalasari, G., Wahyuni, E., \& Karsih. (2016). Asesmen Teknik Nontes dalam Perspektif BK Komprehensif. Jakarta: PT Indeks.

Kwon, M., Lee, J. Y., Won, W. Y., Park, J. W., Min, J. A., Hahn, C., ... Kim, D. J. (2013). Development and Validation of a Smartphone Addiction Scale (SAS). PLoS ONE, 8(2). https://doi.org/10.1371/journal.pone.00 56936

Lee, C., \& Lee, S. J. (2017). Prevalence and predictors of smartphone addiction 
proneness among Korean adolescents.

Children and Youth Services Review,

77(April), 10-17.

https://doi.org/10.1016/j.childyouth.20

17.04 .002

Lee, H. K., Kim, J. H., Fava, M., Mischoulon, D., Park, J. H., Shim, E. J., ... Jeon, H. J. (2017). Development and validation study of the Smartphone Overuse Screening Questionnaire. Psychiatry Research, 257, 352-357. https://doi.org/10.1016/j.psychres.2017. 07.074

Lopez-fernandez, O. (2013). Prevalence of Problematic Mobile Phone. X(X). https://doi.org/10.1089/cyber.2012.026 0

López-Fernández, O., Honrubia-Serrano, M. L., \& Freixa-Blanxart, M. (2012). Spanish adaptation of the "Mobile Phone Problem Use Scale" for adolescent population. Adicciones, 24(2):123-.

Mahmoodi, H., Nadrian, H., Shaghaghi, A., Jafarabadi, M. A., Ahmadi, A., \& Saqqezi, G. S. (2018). Factors associated with mental health among high school students in Iran: Does mobile phone overuse associate with poor mental health? Journal of Child and Adolescent Psychiatric Nursing, 31(1), 6-13. https://doi.org/10.1111/jcap.12202

Mardhiyatun, I. (2015). Penggunaan Smartphone dalam Meningkatkan Minat Berkonsultasi Siswa SMAN 2 Wonosari. UIN Sunan Kalijaga Yogyakarta.

Nalwa, K., \& Anand, A. P. (2004). Internet Addiction in Students: A Cause of Concern. CyberPsychology \& Behavior, 6(6).

Nengsih, N. (2018). The Impact of Facebook Social Networking Sites on Youth Psychology Development. ENLIGHTEN: Jurnal Bimbingan Konseling Islam, 1(2), 95-107. https://doi.org/10.32505/enlighten.v1i2 .761

Novalius, F. (2018). Indonesia Pengguna Smartphone Ke-4 Dunia, Begini Tekad Menprin Dongkrak Industri Telematika. Retrieved from https://economy.okezone.com/read/20 18/02/17/320/1860752/indonesiapengguna-smartphone-ke-4-duniabegini-tekad-menperin-dongkrakindustri-telematika

Putri, A. Y. (2018). Hubungan antara kecanduan smartphone dengan kualitas tidur pada remaja skripsi. UIN Sunan Ampel Surabaya.

Rogozin. (2012). Physics Learning Instruments of XXI Century. Proceedings of The World Conference on Physics Education 2012.

Tri, A. (2014). Dampak Penggunaan Smartphone Pada Remaja Terhadap Interaksi dalam Keluarga di Kabupaten Sleman. Universitas Negeri Yogyakarta.

Wati, S. (2017). Efektivitas Pendekatan Konseling Kognitif Perilaku dalam Mengatasi Dampak Negatif Alat Komunikasi (Smartphone) pada Peserta Didik Kelas XI SMK PGRI 4 Bandar Lampung Tahun 2015-2016. IAIN Radenintan Lampung.

Widharsa, C. S. (2018). 2 Siswa Kecanduan Smartphone, Disdikbud: Penggunaannya Dievaluasi. Retrieved from https://news.detik.com/berita-jawatimur/d-3839164/2-siswa-kecanduansmartphone-disdikbudpenggunaannya-dievaluasi

Widuri, H. (2010). Kebutuhan Dasar Manusia (Aspek Mobilitas dan Istirahat Tidur). Yogyakarta: Gosyen Publishing.

Winskel, H., Kim, T.-H., Kardash, L., \& Belic, I. (2019). Smartphone use and study behavior: A Korean and Australian comparison. Heliyon, 5(7), e02158. 
https://doi.org/10.1016/j.heliyon.2019.e 02158

Woods, H. C., \& Scott, H. (2016). \#Sleepyteens: Social media use in adolescence is associated with poor sleep quality, anxiety, depression and low self-esteem. Journal of Adolescence, 51, 41-49. https://doi.org/10.1016/j.adolescence.2 016.05.008

Yuni, R. S., \& Pieewan, A. C. (2016). Hubungan Intensitas Penggunaan Smartphone dengan Disiplin Belajar Siswa. Jurnal Pendidikan Sosiologi, 1-16.

Yusuf, S., \& Nurihsan, A. J. (2010). Landasan Bimbingan \& Konseling. Bandung: Remaja Rosdakarya. 